\title{
Clinical Profile of Patients with Tetralogy of Fallot admitted for Surgery at a Cardiac surgical centre
}

\author{
Otaigbe BE, Kumar S \\ Department of Paediatric Cardiology. Madras Medical Mission, Chennai. India.
}

\section{ABSTRACT}

Introduction: Tetralogy of Fallot (TOF), a conotruncal defect, has been documented to be associated with chromosome abnormalities, single gene syndrome (22q11 microdeletion), known teratogens, with the rest associations being multifactorial. This study was carried out to determine the clinical profile and associated risk factors in patients with TOF admitted for surgical repairs.

Methods: Case files of all patients admitted for Tetralogy of Fallot over a period of one year were retrieved from the Medical Records Department and reviewed. Data on the patients' and their family history and associated cardiac anomalies were noted.

Results: There were 54 patients, 37 males and 17 females, with a mean age of 6.8 years \pm 7.1 . Sixty percent were born between July and December, $81.5 \%$ as full term and $44 \%$ as first born. Twentysix percent were born into consanguineous marriages. Five patients had dysmorphic features. Associated cardiac anomalies included right aortic arch, pulmonary atresia, dextrocardia and left superior vena cavae.

Conclusion: The associated risk factors noted in this study were male sex, birthdates between July and December, first born and increased paternal age. Other risk factors were consanguinity and specific patterns of cardiovascular diseases associated with 22q 11 deletions. This suggests a multifactorial etiology for TOF.

Keywords: associated risk factors, cardiac anomalies, demographic factors, Tetralogy of Fallot

\section{INTRODUCTION}

Tetralogy of Fallot (TOF), a conotruncal heart defect, is now known to have heterogeneous etiologic ${ }^{1,2}$ and risk factors ${ }^{3}$.Several genetic alterations associated with it include trisomy 21, 22q11 deletion, and JAG mutations ${ }^{2}$. Other associated factors include race, ethnicity, socioeconomic status, demographic and reproductive factors and factors in life style and environment. Cases of Tetralogy of Fallot associated with severe pulmonary artery anomalies, extracardiac anomalies, intrauterine growth retardation, increased
Nuchal translucency and polyhydramnios are more likely to have $22 q 11$ deletions ${ }^{4}$. Whites and Hispanics have a higher rate of TOF than African-Americans ${ }^{5,6}$ and a higher rate of TOF is seen in Blacks than in Hispanics. Seasonal variation ${ }^{7,8}$ with higher rates in children born

Correspondonce:

Dr Barbara Edewele Otaigbe

Department of Paediatric Gardiology Madras Medical

Mission, Chennai, India

Tel no: +2348023193927

E-mail -bariejoe64@yahoo.com 
between July and December has been reported. Some studies have shown that TOF is more common in the urban area $^{7}$ and associated with regional ${ }^{8}$ differences. Maternal age does not appear to influence the risk of TOF 6,9 TOF is more common in males ${ }^{6,7,10}$. Low birth weight and gestational age $\mathrm{e}^{8,11,12}$ are associated with increased risk. Twins are rarely affected ${ }^{13},{ }^{14}$.

Life style, socioeconomic status and environment have been shown to influence the risk of TOF. Maternal occupation in clerical and sales or factory fields ${ }^{12}$ and psychosocial or emotional stress ${ }^{13}$ may increase the risk of all conotruncal defects. Paternal ${ }^{12}$ exposure to radiation and general anaesthesia, maternal ${ }^{14}$ exposure to dyes and not to organic solvents, pesticides, microwave ovens, glues and plastics were implicated. Studies show no relationship of TOF with maternal alcohol use ${ }^{14}$, cigarette smoking or drug ingestion ${ }^{15}$ but maternal diabetes and exposure to retinoic acid and maternal phenylketonuria ${ }^{12}$ are shown to increase the risk of conotruncal defects. Various studies have reported a reduction in conotruncal defect rates with prenatal multivitamin use $^{16}$.

Contrasting reports show that TOF is not associated with consanguity ${ }^{17}$ and that it is higher in children of consanguineous parents ${ }^{18}$.

This study was carried out to determine the clinical profile and documented risk factors in children admitted for palliative or definitive surgery for TOF.

\section{METHODS}

This is a retrospective chart review of patients who were admitted for TOF over a period of one year, from June 2006 to May 2007. We included patients who had had previous systemic to pulmonary artery shunts and TOF with pulmonary atresia. The data documented into a proforma included the patient's age, sex, birth order, month of birth, gestational age, method of delivery, family history of cardiac disease, parental consanguinity, maternal disease and fetal loss and ages of parents. Additional associated cardiac anomalies were also noted. The data was analysed using SPSS version 11.0

\section{RESULTS}

There were 54 patients retrospective chart review into this study with a male: female ratio of $2.2: 1$. The mean age was 6.8 years \pm 7.1 . The maximum age was 40 years and the youngest patient was one month old. The age at first appearance of symptoms was at birth in $7(13 \%)$, within the first one week of life in one child, between one month and one year in 16 (29.6\%), between one year and five years in 20 (37\%) and after five years of age in 10 (18.5\%).

Echocardiographic diagnosis of a heart disease was made within one month of birth in 8 patients $(14.8 \%)$, within one year in $15(27.7 \%)$, between one and five years in $19(35.2 \%)$ and $12(22.3 \%)$ after five years of age One patient each was diagnosed at 11 years and 38 years respectively.

Five $(9.3 \%)$ patients had dysmorphic features and extracardiac anomalies (mainly orthopaedic) were seen in eight $(14.8 \%)$ patients.

Propanolol hydrochloride was never used in 33 (61.1 $\%)$ of the patients, was commenced on admission for surgery in $12(22.2 \%)$ and was used routinely by only $9(16.7 \%)$. Nine patients had B-T shunts (16.7 $\%)$. There was only one death $(1.9 \%)$ in a 55 -day old female, the first child of a consanguineously married couple, with symptoms noticed on the $50^{\text {th }}$ day of life and with a history of recurrent spells subsequently. She was admitted to hospital two days later for medical management but had an emergency B-T shunt. The child died a few hours after surgery from a low cardiac output syndrome.

There was one case of Marfans syndrome. Four of the patients (7.5\%) were Africans made up of three males and one female aged between seven and 12 years and they all presented with severe infundibular, valvar and supravalvar stenosis. One of them had a right aortic arch.

The detailed demographic profile of the patients is summarized in Tables 1 - 3. About $60 \%$ were born between July and December and none in the month of February. One patient had two siblings with complex heart disease, one with a cousin with truncus arteriosus, another with a second cousin with ventricular septal defect (VSD) and a patent ductus arteriosus (PDA) (Table 1), and one sibling had died at one month of age after surgery for a cyanotic congenital heart disease. There was only one documented case of maternal illness with Diabetes (Table 2).

In associated cardiac anomalies, an 18-month old female with dextrocardia had pulmonary atresia, bilateral superior vena cavae, right aortic arch, atrial septal defects (ASD), PDA and multiple aortopulmonary collaterals (MAPCAs). In five patients with dysmorphic features, all had a right aortic arch, $40 \%$ had pulmonary atresia, $20 \%$ infundibular hypoplasia, severe infundibular and valvar pulmonary stenosis and hypoplastic right pulmonary artery. The two patients with pulmonary atresia had absent native 
central pulmonary As, major MAPCAs and large VSDs demonstrated by CT angiogram. One patient had an abnormal origin of the right and left coronary arteries and a separate origin of the circumflex coronary arteries (Table 3).

Table 1. Characteristics of patients with Tetralogy of Fallot ( $\mathrm{n}=54$ )

\begin{tabular}{|c|c|c|}
\hline$\underline{\text { Variables }}$ & $\underline{\text { No }}$ & \% \\
\hline \multicolumn{3}{|l|}{ Sex } \\
\hline Male & 37 & 68.5 \\
\hline Female & 17 & 31.5 \\
\hline \multicolumn{3}{|l|}{ Age groups } \\
\hline 1 - 30 days & 1 & 1.9 \\
\hline 31 days - 2 years & 14 & 26 \\
\hline $2-6$ years & 18 & 33.2 \\
\hline $6-12$ years & 9 & 16.7 \\
\hline$>12$ years & 12 & 22.2 \\
\hline \multicolumn{3}{|l|}{ Month of birth } \\
\hline Jan-April & 15 & 27.8 \\
\hline May -August & 18 & 33.2 \\
\hline Sept-December & 21 & 39 \\
\hline \multicolumn{3}{|l|}{ Birth weight } \\
\hline$<1.5 \mathrm{~kg}$ & 0 & 0 \\
\hline $1.5-2.5$ & 5 & 9.3 \\
\hline$>2.5-3.9$ & 18 & 33.2 \\
\hline 4 and above & 1 & 1.9 \\
\hline Not recorded & 30 & 55.6 \\
\hline \multicolumn{3}{|l|}{ Birth order } \\
\hline $1^{\text {st }}$ & 24 & 44.4 \\
\hline $2^{\text {nd }}-5^{\text {th }}$ & 23 & 42.6 \\
\hline Above $5^{\text {th }}$ & 1 & 1.9 \\
\hline Not recorded & 6 & 11.1 \\
\hline \multicolumn{3}{|l|}{ Gestational age } \\
\hline Preterm & 9 & 16.7 \\
\hline Term & 44 & 81.5 \\
\hline Postdate & 1 & 1.9 \\
\hline \multicolumn{3}{|l|}{ Mode of delivery } \\
\hline Normal vaginal delivery & 37 & 68.5 \\
\hline Caesarean section & 9 & 16.7 \\
\hline Not recorded & 8 & 14.8 \\
\hline \multicolumn{3}{|l|}{ Parental consanguinity } \\
\hline Yes & 15 & 27.8 \\
\hline No & 32 & 59.2 \\
\hline Not recorded & 7 & 13 \\
\hline
\end{tabular}

\section{Family history of heart} disease

Yes

14.9

No

26

48.1

Not recorded

Table 2. Parental characteristics of patents with Tetralogy of Fallot $(n=54)$

\begin{tabular}{lrr} 
Variables & No & Percentage \\
\hline Maternal age & & \\
$<25$ years & 2 & 3.7 \\
$>25$ years & 9 & 16.7 \\
$>35$ years & 2 & 3.7 \\
Not recorded & 41 & 75.9 \\
\hline Paternal age & & \\
$<25$ years & & 0 \\
$>25$ years & 0 & 11 \\
$>35$ years & 9 & 13 \\
Not recorded & 7 & 76
\end{tabular}

$\begin{array}{lrr}\text { History of previous } & & \\ \text { maternal fetal loss } & 4 & 7.5 \\ \text { Yes } & 40 & 74.1 \\ \text { No } & 10 & 18.5 \\ \text { Not recorded } & & \\ \text { History of maternal illness } & & \\ \text { Yes } & 1 & 1.9 \\ \text { No } & 43 & 79.6 \\ \text { Not recorded } & 10 & 18.5\end{array}$

TABLE 3. Associated cardiac anomalies in patients with Tetralogy of Fallot $(n=54)$

\begin{tabular}{|c|c|c|}
\hline Type & Number & Percentage \\
\hline Right aortic arch & 15 & 27.8 \\
\hline Pulmonary atresia & 6 & 11.1 \\
\hline $\begin{array}{l}\text { Multiple aorto-pulmonary } \\
\text { collateral (MAPCAs) }\end{array}$ & 12 & 22.2 \\
\hline Bicuspid pulmonary valve & & \\
\hline $\begin{array}{l}\text { Dysplastic pulmonary } \\
\text { Valve }\end{array}$ & 7 & 13 \\
\hline & 3 & 5.7 \\
\hline Dextrocaraı & 1 & 1.9 \\
\hline $\begin{array}{l}\text { Left superior vena cavae } \\
\text { (SVC) }\end{array}$ & 4 & 7.4 \\
\hline
\end{tabular}




\begin{tabular}{lcr}
$\begin{array}{l}\text { Multiple ventricular septal } \\
\text { defect (VSD) }\end{array}$ & 9 & 16.7 \\
\hline $\begin{array}{l}\text { Coronary Anomalies } \\
\text { Patent ductus arteriosus }\end{array}$ & 8 & 14.8 \\
\hline (PDA) & 13 & 24 \\
\hline Atrial septal defects (ASD) & 6 & 11.1 \\
\hline Patent fossa ovalis (PFO) & 7 & 13
\end{tabular}

\section{DISCUSSION}

The prevalence of Tetralogy of Fallot from this one-year study of patients admitted for surgery was $13.6 \%$. This figure cannot be used as an estimation of the prevalence of Fallot's tetralogy because it is taken from a select group of the privileged to have surgery and this is a small number when compared to those patients who are still undiagnosed and those diagnosed but who cannot afford surgery.

The male preponderance shown in this study is consistent with other studies ${ }^{6,7,10}$. It is interesting that none of the 54 patients was born in the month of February. Over 60 $\%$ were born between July and December as reported by others ${ }^{7,8}$. This may indicate seasonal variations as risks for Fallot's tetralogy. The risk was found to be higher in first born children.

In this study, we did not find that low birth weight is associated with increased risk of TOF as reported by others ${ }^{10,12,14}$. We had no twins as patients in this study, though a high risk in twins and siblings has been documented 6,11 .Three of the patients had siblings or cousins with congenital heart disease. About $50 \%$ of the documented parents were consanguineously married which is in line with other reports ${ }^{16,17}$.
Unfortunately, other factors of life style and environment were not determined in the patients' files. These and the lack of information on parental socioeconomic group, psychosocial or emotional stress, paternal exposure to radiation and general anaesthesia , maternal exposure to dyes, alcohol use, cigarette smoking, drug ingestion and prenatal multivitamin use are the limitations of this retrospective study. There was only one case of maternal diabetes, which is known to elevate the risk for conotruncal defects ${ }^{2}$.

Tetralogy of Fallot is one of the cardiovascular malformations associated with Deletion 22q11. Unfortunately, Fluorescence In Situ Hybridization (FISH) was not done; however, all the patients with dysmorphic features ( 9 $\%$ of patients) had a right aortic arch and some had other anomalies associated with Deletion 22 q11 such as bicuspid valves, hypoplastic infundibulum, MAPCAS and pulmonary atresia. These features were also seen in nonsyndromic patients.

\section{CONCLUSIONS}

The clinical profile of patients with TOF has shown some associated risk factors such as male sex, born between July and December, first born and increased paternal age. Other risk factors were consanguinity and specific patterns of cardiovascular diseases associated with $22 q 11$ deletions. This suggests a multifactorial etiology for TOF and highlights the importance of demographic factors. 


\section{REFERENCES}

1. Wulfsberg EA, Zintz EJ, Moore JW. The inheritance of conotruncal malformations: a review and report of two siblings with TOF with PA. Clin Genet. 1991;40:12-16.

2. Goldmuntz E, Lin A. Genetics of congenital heart diseases In: Moss and Adams' Heart Disease in Infants, Children and Adolescents Including the Fetus and Young Adults. Moss AJ. Adams F, editors. Philadelphia, PA: Lippincott Williams \& Wilkins, 2008. P. 545-72

3. Birth Defects Risk Factor Series. Conotruncal Heart Defects, Texas Department of State Health Services. 2007. Accessed April 2008.

4. Boudjemline Y, Fermont L, Le Bidois J, Villian E, Sidi D, Bonnet D. Can we predict 22q11 status of fetuses with tetralogy of Fallot? Prenat Diagn. 2002;22:231-4.

5. Botto LD, Correa A, Erickson JD. Racial and temporal variation in the prevalence of heart defects. Pediatrics. 2001a;107:e32.

6. O'Mailey CD, Shaw GM, Wasserman CR, Lammer EJ. Epidemiologic characteristics of conotruncal heart defects in California, 1987-1988. Tetralogy. 1996;53:374-7.

7. Pradat P, Francannet $C$, Harris JA, Robert E. The epidemiology of cardiovascular defect, part 1: a study based on data from three large registries of congenital malformations. Paediatr Cardiol. 2003;24(3):195-221.

8. Rasmussen SA, Moore CA, Paulozzi LJ, Rhodenhiser EP. Risk for birth defects among premature infants: A population -based study. J Pediatr. 2001;138:668-73.
9. Francannet C, Lancaster PA, Pradat P, Cocchi G, Stoll C. The epidemiology of three serious cardiac defects. A joint study between 5 centres. Eur J Epidermiol. 1993;9:607-16.

10. Lary JM, Paulozzi LJ. Sex differences in the prevalence of human birth defects: a population based study. Teratology. 2001;64:237-51.

11. Riley MM, Halliday JL, Lumley JM, Congenital malformation in Victoria, Australia, 1983-95; an overview of infant characteristics. J Paediatr Child Health. 1998;34:233-40

12. Ferencz C, Rubin JD, McCarter RJ, Brenner JI et al. Congenital heart disease prevalence at livebirth. Am J Epidemiol. 1985;121:31-6.

13. Nora JJ, Gillilard JC, Sommerville RJ, McNamara OG, Congenital Heart Disease in Twins, New England J Med. 1967;277:568.

14. Folger GM, Tetralogy of Fallot in Twins. Southern Medical Journal. 1968;61:40-2.

15. Wasserman CR, Shaw GM, O'Mailey CD, Tolarova MM, Lammer EJ. Parental cigarette smoking and risk for congenital anomalies of the heart, neural tube or limb. Teratology. 1996;53;261-7.

16. Botto LD, Mulinare J, Erickson JD. Periconceptual multivitamins use and the occurrence of conotruncal heart defects; results from a population-based case-controlled study. Pediatrics. 1996;98:911-7.

17. Becker S.M., Al Halees Z., Molina C. Paterson, R.M. Consanguity and congenital heart disease in Saudi Arabia. Am. J. Med. Genet. 2001;99:8-13.

18. Der Kaloushan VM, Ratl M, Malong J, Hatem J et al, Tetralogy of Fallot with pulmonary atresia in siblings. Am J Med Genet. 1985;21(1):119-22. 